\title{
Andrew Fuller's Soham Farewell Sermons: Context and Text
}

Stephen R. Holmes and Jonathan Woods

St Mary's College, University of St Andrews.

\begin{abstract}
The notes of Andrew Fuller's two sermons preached on his last Sunday (in October 1782) as pastor of the church in Soham, before his departure for Kettering, are unusually full compared to his other sermon notes from the period. They have survived only in a shorthand that has previously been regarded as uninterpretable, and so have not previously been published. In this article, the authors describe how they learned to read his shorthand, and present a transcription of the notes, together with some context to underline the importance of these sermons.
\end{abstract}

\section{Introduction}

Andrew Fuller (1754-1815) is remembered as one of the greatest British Baptist leaders and theologians. ${ }^{1}$ His role in organising (what is often regarded as) the first modern missionary society, with William Carey, in 1792, and his great 1785 work, The Gospel Worthy of All Acceptation, ${ }^{2}$ both number amongst the most significant productions of his denomination. His beginnings, however, were humble. His father, Robert, was a tenant farmer, and Andrew's childhood education was as minimal as would be expected; he attended a free school for a few years in his childhood home of Soham, a small Fenland village, roughly midway between Newmarket and Ely. The more sympathetic of his early biographers claims he developed through this 'a taste for reading'; 3 the less sympathetic records 'only the common rudiments of an English education'. ${ }^{4}$ Both, of course, might be true: an intelligent child given the rudiments of literacy, and access to texts, might well develop a love of books.

This lack of education is, however, significant. Fuller became the primary preacher of the small Particular Baptist church in Soham in 1774, aged only nineteen, and accepted a call to the pastorate soon after his twenty-first birthday. His ordination service brought him into contact with Robert Hall, senior. The impact of Hall might be judged by the fact that, within a few weeks of the ordination service, the church had applied to join the Northamptonshire Association. ${ }^{5}$ Fuller was soon introduced to the Association ministers, including John Ryland, junior (pastor at Northampton), and John Sutcliff (of Olney). Fuller's theological development during these years was remarkably rapid, no doubt in part due to the conversations he had with other ministers in the Association, and the resources they were able to supply him with, or point him towards. An unpublished manuscript, bearing the date ' 1777 or 1778 ', demonstrates that, by that date, he had left behind the hyper-Calvinist tradition of the Soham church decisively, and was reading both Biblical languages, and highly technical theology, with some ease. ${ }^{6}$ By about 1781 , he had

\footnotetext{
${ }^{1}$ Peter J. Morden, The Life and Thought of Andrew Fuller (1754-1815) (Milton Keynes: Paternoster, 2015) is now the standard biography; several volumes of a new critical edition of Fuller's works, under the general editorship of Michael Haykin, are now available, and the whole series promises to be invaluable when complete. Haykin (ed.) The Works of Andrew Fuller (projected 15 vols), (Berlin: De Gruyter, 2016-).

2 Andrew Fuller, The Gospel Worthy of all Acceptation (Northampton: Thomas Dicey, 1785); a second edition was published in 1801, which is the edition found in the various nineteenth-century collections of Fuller's on which we are still largely reliant.

${ }^{3}$ Andrew Gunton Fuller, Men Worth Remembering: Andrew Fuller (London: Hodder \& Stoughton, 1882), p. 22.

${ }^{4}$ John W. Morris, Memoirs of the Life and Death of the Rev. Andrew Fuller (London: Wrightman and Cramp, $\left.1826^{2}\right)$, p. 17.

${ }^{5}$ Morden, Life and Thought, loc. 1395 of Kindle edition, referencing Fuller's own history of the church.

${ }^{6}$ Andrew Fuller, 'Thoughts on the Power of Man to do the Will of God' unpublished MS held at Southern Baptist Theological Seminary, Q98.F95.
} 
completed the manuscript of his first draft of The Gospel Worthy of All Acceptation, ${ }^{7}$ which ranks still amongst the most significant theological treatises produced by any British Baptist author.

It is no surprise that larger and more influential churches than the little village meeting in Soham became interested in Fuller, and when the Kettering cause became vacant, they pursued him with vigour, beginning in 1779. Fuller initially resisted: his heart was with his people in Soham, few though they were. They were so few, however, that they could not pay him a stipend he could live on, and his theological shifts had left some, at least, disgruntled. For over two years he resisted the invitation to move on, but in May 1782 he informed the Soham church that he had accepted the call to Kettering. He left in early October that year. We have Fuller's Diary from the earlier part of this period, which records endless agonising over the decision, ${ }^{8}$ but does not really give us an account of how he defended it to the church.

It is very hard not to marvel at the rapidity of the development of Fuller's mind in these few years. To become able in Greek and Hebrew in the course of six years, whilst serving as a pastor, would itself be remarkable; to combine that with reading oneself into the key theological controversies of the age, and writing the decisive response to them, is astonishing. Unfortunately, with the sole exception of the Diary, which (in true evangelical style) is more concerned with the state of Fuller's heart than that of his mind, the published works all date from several years after this formative period. The very recent discovery of the 1777-8 MS referenced above, by Michael Haykin, has already enabled Fuller scholars to revise significantly our account of the development of his theology, ${ }^{9}$ but this is a single document, and so there is no narrative of exploration or development available from it.

Bristol Baptist College holds five books of sermon notes, which do not quite go back to the beginnings of Fuller's ministry, but do begin in April 1778, less than three years after his ordination in Soham. ${ }^{10}$ They cover his Soham ministry extensively, and include also a few sermons from his early ministry in Kettering. Here we might hope to find a picture of the mind developing, seeing the interests that successively commanded his attention, and tracing changes of emphasis and indeed substance in his thought. Unfortunately, all these notes are written in a shorthand that previous scholars have found impossible to decipher, as many of them have noted. Morden's comment is typical:

Fuller seems to have devised his own shorthand system, although he drew from elements of other schemes which were in common use ... There is a 'key' to Fuller's shorthand inserted at the front of the bound volume of sermons. This was originally done by John G. Fuller, and copied by Gunton Fuller. Unfortunately, the key is not especially helpful. It omits many symbols that Fuller used, and does not seem to be particularly accurate with regards to those it does include. The inadequacy of the key and the poor state of many of the pages in the bound

\footnotetext{
7 Morden notes that the MS would be revised before publication in 1785, but not significantly. Morden, Life and Thought, loc.1553.

${ }^{8}$ See diary entries for (e.g.) Nov. 9 and 28, 1780; Mar. 5, Apr. 2, 10, and 19; May 10 and 20; Jul 12; Sep 21, 1781. Haykin (ed.) Works vol.1: The Diary of Andrew Fuller, 1780-1801 (ed. Michael D. McMullen and Timothy D. Whelan) (Berlin: De Gruyter, 2016).

${ }^{9}$ A forthcoming St Andrews PhD thesis by David Rathel, under the supervision of one of the present authors, demonstrates this claim fully and helpfully.

${ }^{10}$ There are five books, now bound together in one volume, including some hundreds of pages, and a similar number of sermons, altogether. The authors are very grateful indeed to Bristol Baptist College, and particularly to Michael Brealey, the archivist there, for allowing them to examine the manuscripts, and for supplying them both with digital images of the entire text. Hereafter these texts are referenced as 'Bristol

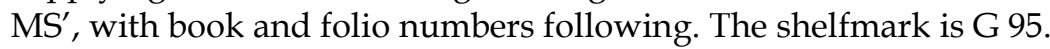


volume, together with Fuller's handwriting (which is not always easy to decipher in longhand), make it difficult to discern the meaning of his shorthand with any certainty. ${ }^{11}$

\section{Deciphering Fuller's Shorthand}

Any reader looking at the supplied ' $\mathrm{key}^{\prime}$, and a random page from the MS, will agree with Morden's negative evaluation; the shorthand appears unintelligible. However, in the fifth book of the MS, there is a cramped page of shorthand headed 'Confession of Faith, Oct. 71783 '. ${ }^{12}$ Students of Fuller will recognise this date as that of Fuller's induction (after the customary year's trial) to the pastorate of the Kettering church. He supplied a confession of faith as part of that service, ${ }^{13}$ the text of which is in Gunton Fuller's biography. With the help of the key, it is possible to establish that the shorthand text is identical to that published by Gunton Fuller, and so that these texts offer a 'Rosetta Stone' for the interpretation of Fuller's shorthand.

Contrary to Morden's estimation quoted above, the supplied 'key' contains everything necessary to read the shorthand. The reader has to recognise the nature of the text: generally (and in common with other shorthand systems), Fuller's shorthand notes contain the consonants only of a word, and the reader has to supply the vowels; he runs shorthand marks together, so the reader is often faced with a fairly complex squiggle that needs unpicking into separate signs; also, although several letter signs are straight lines differentiated only by angle, Fuller is unhelpfully imprecise in his writing of his shorthand, using a near-horizontal line when an oblique line was called for, for example, but he is imprecise in fairly consistent ways.

That said, the industrious reader can become conversant in Fuller's shorthand in a few tens of hours, if s/he starts with the Confession. Some combinations of signs remain opaque, and the occasional longhand intrusion into the shorthand is, perhaps surprisingly, often more difficult to interpret than the shorthand itself. ${ }^{14}$ Despite these problems, the authors are presently able to read with confidence perhaps $80 \%$ of what Fuller wrote in shorthand, and to extrapolate from context most of the rest. The hardest problem remaining is numerals, particularly in supplied Biblical references; sometimes these are very clear; other times, it appears that a numeric shorthand is in use, which has not yet been deciphered adequately. Many of the Biblical references supplied below are deduced from context, rather than read.

In the fifth notebook in the Bristol MS there are two sermons, whose notes are much longer than most in the collection, which are clearly identified by longhand headings as the sermons Fuller preached on the morning and evening of his last Sunday in Soham. ${ }^{15}$ These seem to be among the more interesting, and less difficult sermons in the corpus. On the one hand, his notes are far more extensive-perhaps by a factor of 3-than typical sermons. On the other, the shorthand notes for these sermons are generally clean, careful, and well-spaced, which is not the case everywhere. There can be little doubt, given the context of his departure from Soham, that he worked especially hard on these sermons, and the extended notes perhaps suggest both that he was concerned to say the right thing, and that he was sufficiently aware of the emotion of the moment that he wanted

\footnotetext{
11 Morden, Life and Thought, loc. 1464, n.34

12 Bristol MS, V.148.

13 This was normal practice across nonconformist churches in the eighteenth century.

14 In particular, Fuller very often abbreviated longhand words to the first three or four letters and the last; dec...n' (to take an example) clearly invites several possible interpretations, between which only context can decide.

15 Bristol MS, V.89-92.
} 
the help of more extensive notes than usual. The texts contain sections showing careful oratorical construction that would certainly have been preached verbatim, and powerfully.

The pages of the manuscript show marks of being folded into sixths, which we assume is evidence of their being taken in a pocket into the pulpit and there used. ${ }^{16}$ The notes demonstrate (primarily through the very regular use of 'etc.' and ellipses, which clearly indicate an intention on Fuller's part to fill out a Biblical quotation, or to expand a point extempore) that this was not the full wording of what he would say; ${ }^{17}$ nonetheless, the key themes he intended to expound, and the key points of application he intended to make, are clear in the shorthand notes. Given the struggle and emotion of Fuller's departure from Soham, and the historical importance of his later ministry, the significance of these two sermons is very clear.

A word on the status of these texts is in order. Readings are secure unless otherwise indicated. 80$90 \%$ of what follows is of this status, and here the authors would be very surprised to have to emend the text. In other places a reading is marked as uncertain by a question mark in brackets following the word - [?], or the text is marked as unclear, and no reading is supplied. In what follows there is only one substantive point, and that relatively minor, where the meaning of a portion of the sermon is affected by these uncertainties; everywhere else, it is clear what Fuller intended to say, even in those few instances where it is not yet possible to decipher his notes exactly. That said, this project is in its early stages, and somewhat better texts, with less uncertainty and perhaps a handful of emended readings, should be produced, by the present authors or others, in the coming years.

\section{Morning Sermon}

Preached in the morning of the last sabath [sic] of my being at Soham. Oct $1782^{18}$

Romans 8:28.

It seems an easy matter to believe God's declarations at some periods of our life, and as hard a thing [unclear]. It's an easy thing when we are first converted, or when God smiles upon us by his providence, to believe the truth which the words I have read teach us about. A much harder thing in times when we are covered as with a cloud in God's anger and all things seem to go against us. These are the times for what the apostle calls "the trial of our faith!"19 Genesis 39:12 These are the times in which we are ready to say how can these things be? and have reason to say 'Lord increase our faith!' 'Lord I believe' etc.

\footnotetext{
${ }^{16}$ Various biographers have suggested that Fuller preached without notes (see, e.g. Keith S. Grant, Andrew Fuller and the Evangelical Renewal of Pastoral Theology (Milton Keynes: Paternoster, 2013), pp. 87-90); the evidence of the mss suggests that he did in fact carry notes (whether he consulted them or not) fairly often, at least in the period 1778-1783 - although it is striking that there are many consecutive pages unfolded, suggesting that they may not have been taken into the pulpit, followed by many folded. This might indicate variations over time in Fuller's practice.

17 We in fact appear to have the ipsisimma verba of perhaps three of Fuller's sermons; Joseph Belcher (ed.), The Last Remains of the Rev. Andrew Fuller... (Philadelphia, PA: American Baptist Publication Society, 1856), includes three lengthy texts (one about 4500 words; two others about half that), and a note that some of the material was sourced from William Gurney, a famed shorthand reporter later responsible for 'Hansard', the verbatim transcription of Westminster parliamentary debates. We might presume that Gurney used his skills to record the sermons he heard word-for-word. The sermons are 'The Conversion of Sinners' (preached June 1, 1802) (pp. 24-47); 'Invitation to the Promised Land' (pp. 99-112); and 'Two Blind Men' (preached June 1802) (pp. 118-132); for the note concerning Gurney, see p. 3; for a note of Gurney's career, see the DNB, sv. 18 Longhand superscription supplied by Fuller, probably at a later date (the ink appears different).

19 1Pet. 1:7
} 
But one thing must not be forgotten, and that is that our changes make no change in the truth of God's declarations. What he says is as true when it seems impossible to us as when it appears ever so plain to us. --- And it is the work of faith to believe in these dark seasons, to say with the Shunammite ${ }^{20}$ 'all is well!' Or as the good man did when [illegible word]! [illegible phrase]. Yes all is well whether we see it so or no. --- say ye to the Righteous etc. ${ }^{21}$

The great ruler of heaven and earth sits at the helm of all affairs, by his power keeps the world and all things in it in motion. All things are full of light[?]; all things work...22 --- The same God who, by his power causeth them to work, by his wisdom guides them in their working, so as they work together, not like the working of a tumultuous mob, but like the manoeuvres of a well-disciplined army. God is Lord of Hosts, and all events in time are but as soldiers which make up his hosts. He says to one etc. ${ }^{23}$ Or it's like the well-ordered working of a machine (a mill) which not only works but works together.--- Or like the well prescribed potions of the physician, made up of different ingredients, which are to have their different effects, but all work together, and for the patient's recovery. Moreover he who has power enough to keep all things at work, and wisdom enough to cause them to work together, has love us enough to make them answer one invariable end, the good of his people. Go to the husbands [sic] who has got 20 servants, plows, go in teams etc. What are all these for? Why, he has our end in view [word unclear] a child to pray. But I would attempt 2 things.

I. To explain in what sense this truth is to be understood.--- Perhaps one reason why we cannot at all times discern the truth of this doctrine is because we don't understand it. A few explanatory remarks then may not be amiss.

1. Not always a perceived good. Through inattention we too often overlook the work of God and the good brought us.--- We are much guilty of this in preventions. God by his kind providence prevents an evil which, had we had our own will, had come upon us, yet we forget this. Exodus 12:17. So again it was good for Jonah to lose his gourd, ${ }^{24}$ being so pleased with it, and apt to forget his God. Yet he did not perceive this.

2. Not always an immediate good.--- Even when we do perceive, it is often a great while first and here, I might bring examples from the experience of almost all the saints, many but [word unclear] Jacob: 'all these things etc.' 25 and Asaph, await but awhile, etc. ${ }^{26}$

3. Not always the particular good which we desire.--- Perhaps the good that we desire would not, all things considered, be good for us. (Jonathan but he had loved [word unclear] the kingdom had not been united - David also \&c.) David desired the life of the child, but that must not be given, but he must be humbled. God had said the child that is born unto thee etc. ${ }^{27}$ David must see that God meant as he said, and that, though he had pardoned him, yet he would take vengeance on - before etc. Perhaps we too little [word unclear] that a good to be humbled and brought down. But God [word unclear] at so Lamentations

\footnotetext{
20 See $2 \mathrm{Ki} .4: 26$

21 Is. 3:10

$\underline{22}$ Rom. 8:28 (the sermon text)

23 See Mt. 8:9

24 See Jon. 4:6ff.

25 Gen. $42: 36$

26 Ps. 73 (which is 'of Asaph' in the title).

27 2Sam. 12:14-20.
} 
3:[reference unclear: 2?] humble thee -- and the good in [words unclear] --but having said this much let us now...

II. Instance in a few things wherein this truth appears.--- It must be the work of an happy eternity to see and go over all the things distinctly[?]! That work etc. But I would mention some few of them, and

1st we may instance in things wherein those who have the [unclear] in them mean no good to the godly. True good to them comes out of [em?]. The world is full of confusion, and the welfare of the godly is far from being in most men's hearts. They plan, they nurture, sometimes they execute their designs and sometimes are disappointed, but yet good is brought to the godly. The Philistines came up against Saul 1 Samuel 28:[reference unclear], thought nothing of David, but God did. Thus often in wars between nation and nation, princes have their [unclear] ambitions [unclear] those to immoral [unclear] that [several words unclear] and God his. Cyrus with Belshazzar. The brangles ${ }^{28}$ of bad men are often blessings to good men for if they agree it is in [unclear]. When one of these brangles [unclear] up Christ was crucified

2nd things which in themselves have no good in them but appear the direct contrary.--Afflictions are the fruits of the fall.--- are unsavoury[?]---. Straits in things of this life seem very lamentable, and yet by these many are brought to God. Here by pride has been brought down "I suffered thee to hunger etc." ${ }^{29}$ We think it very hard and far from being good for a young man to be much afflicted yet Lam. 2:[?] - Dangerous seasons seem undesirable[?] it could appear no good to us for Jonah to be cast into the sea and fish yet ... [unclear] it can appear no good for us to be brought into dark and crooked [unclear] wherein we can see no way of escape, but it excites[?] prayer and gives God opportunity to show himself to be God. Isaiah 16. Hard things easy etc. Psalm 107. These see the wonderful works etc. ${ }^{30}$

The withdrawal of God from us--- makes us prize.... We should say it's good to be here ${ }^{31}$ but God knows otherwise. He causes these to work us into a desire for him - Job. Makes us prize when found ch:[??] in sins. And I could add if it were not too tender a point to touch upon in our collective as well as personal [word unclear].

3rd Things which have much evil in them and are meant to do the godly hurt. It has been all along the wisdom of God to defeat the designs of Satan and his agents, to kill Goliath with his own sword, ${ }^{32}$ and to make that which they count for evil turn to their good. This the cause persecutions intended to iradicate [sic] only spread. Paul and Onesimus. ${ }^{33}$ Joseph was a fretful ${ }^{34}$ boy and though shut out etc. His branches [unclear] ours etc. So in the

\footnotetext{
${ }^{28}$ An obsolete C18th term meaning both 'arguments' and 'muddles'.

${ }^{29}$ Dt. 8:3

30 Ps. 107:24

31 Mt. 17:4

32 1Sam. 17:51

33 Philem. 11

34 Presumably in the archaic sense of 'irritating'.
} 
various triumphs of the wicked over the people of God they have been but as the staff or rod in God's hand.

Howbeit he meant it not so. Thus the temptations of the Devil, if P. [sic, Paul] had never had any of these he could not have said we are not ignorant of his devices. ${ }^{35}$ Satan's sifting was overruled[?] for Job's good.

It has been a question with some whether sins be [unclear] in the 'all things'. This a subject ought to be spoken of with great caution. Some think sin is not meant, but that it is speaking only of what God works. 'Who shall harm you if' etc. ${ }^{36}$ Others have thought $\sin$ is intended, for though sin is wholly evil, yet it is no new thing for God to bring good out of evil. Besides, they think facts are on their side: the sins of others we know are [supply 'worked for good']. It was sin in Joseph's brethren, ${ }^{37}$ and when God did not work as sin, and they meant it for evil, but God overruled it for good. Ps. 76:10. Saul's murder of himself,38 Balaam's curse thought a blessing, 39 Haman's envy, ${ }^{40}$ Christ's death. But do our own sins [supply 'work for good']? They do not of themselves; they work evil, and if God brought good from them no thanks to those who sin. Joseph being sold was for his [unclear] good as well as his. That however no encouragement for they to presume... Let this be as it may. I will make one observation: let none think that sin does a believer no harm; it does harm, and all the harm that is done, and if God in infinite mercy prevent it not, it will be eternal harm. And if he heal the broken bone and the place became the stronger [unclear] before, that does not prove that the fall by which we take it does us no harm - or that we are to break it again. Woe to them that say let us do evil etc. ${ }^{41}$

Use 1. Resignation and confidence, power, wisdom and love. Working, working together, and for good.

2. Let us remember 'it is to those who love God' etc. 42 none else will submit nor take things well. Chastise a slave and he will hate, but [chastise] a child and, because he loves, it will do him good.

But I must close! May God bless you and add a blessing to what has been said!

\section{Evening Sermon}

The farewell sermon on leaving Soham. Oct. 1782.43

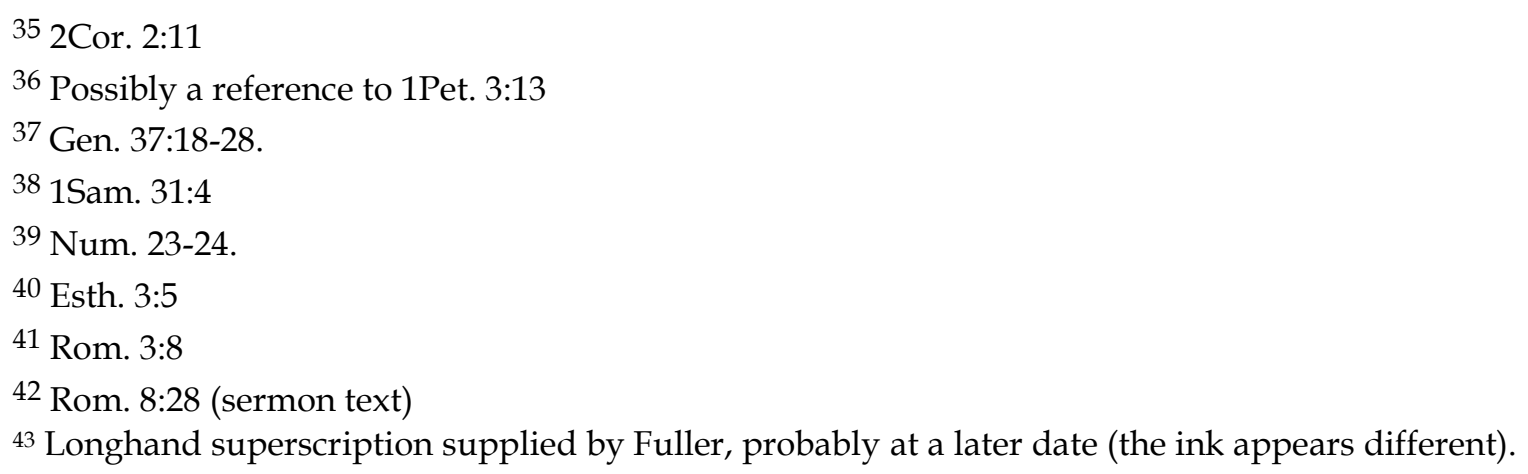


Philippians 1:6 God has declared himself willing that the heirs of promises etc. ${ }^{44}$ who have etc. Had it not been for the promises of God, they would have despaired of ever arriving[?]. The more they became acquainted with their hearts, the more they would have despaired. It resembles Israel: when [they?] came out of Egypt, they would have died in the wilderness. But [unclear] he that brought them out had engaged to bring them to the good land. So he .... But one main question with many is, 'is the work begun? In order to settle this we must....

I. Consider something of the work itself (and then afterwards confirm what is asserted that etc. [supply 'he will perform it until the day of Jesus Christ']). The work itself is here called a good work---. A work of God's beginning and carrying on too. Some in the Dissenting world ${ }^{45}$ have, I think, [unclear] attempted. Ridicule this idea (Fisher ${ }^{46}$ ) but it is a work - there is something done, something produced. It is no enthusiasm---. There is not only a work for us by Christ but in us by the Holy Ghost. Not only a word to us in the Scriptures but a work in us by the Spirit...

And a good work too. All God's works are good, very good--but this good by way of eminence. It is the top place[?] of all his work. That of the creation was but a shadow of it, and a fit shadow. Tohu and bohu! The spirit of God moved upon etc. or brooded. ${ }^{47}$ Here all the perfections of God appear in brightest[?] colours. Holiness in not only planting but restoring etc.

But let us consider this work of God as distinct from every other work. Not very difficult to distinguish it from that open evil work of the Devil upon the hearts of men, but it is from other works that more resemble it. Here is where we are apt to be deceived. But let us distinguish this divine work:

$1^{\text {st. }}$ From any work of a man's self. "Not of ourselves" give references. Various considerations may induce a man to resolve upon and effect a reformation --. Shame induced Saul "I have done foolishly". ${ }^{48}$ Fear Shimei... ${ }^{49}$ So a drunkard through fear of death. Fears of Hell frighten men into a serious work but these effects being self-laid and carried on in their own strength presently decay. Is. 40:30. Besides this [is] only a cutting off the branches. The disposition is not changed. But God's work is at the root. His work brings a man to repent, to all undo whatever he has been doing, or to wish it mending, makes him a new creature. Religion becomes his chosen employment, his calling, his delight, not his task. Hypocrites have

\footnotetext{
44 Possible reference to Heb. 6:17.

${ }^{45}$ It would be possible here to read 'dissenting world' - i.e., the unbelieving community that rejects gospel truth. Our inclination, however, is to read 'Dissenting world', referring to the broad community of Protestant Dissenters. Fuller would speak of 'Dissent' or 'Dissenting' in this sense fairly regularly in his published works (see particularly the preface to The Calvinistic and Socinian Systems Examined and Compared), although not elsewhere followed by 'world'. Fuller's shorthand system has no means of distinguishing capital and lower case letters.

46 Presumably a reference to Edward Fisher, The Marrow of Modern Divinity (London, 1675), which had been republished in 1781, and, famously, occasioned some controversy. According to the list of books he owned in 1798, appended to his diary, Fuller owned the 1781 edition. See Fuller, Diary, p. 223.

47 All references to Genesis 1:1-3; 'tohu' and 'bohu' are transliterations of the Hebrew words translated 'without form' and 'void' in v.3.

48 This is difficult to place. Saul never utters the words 'I have done foolishly' in the KJV; in 1Sam. 13:13, Samuel tells Saul, 'You have done foolishly', and this may be meant; 1Sam.15:22-31 seems to fit the context better, however, showing a self-worked reformation through shame.

49 Reference to 2Sam. 19:18ff.
} 
wrought themselves up to a high pitch of sanctity but as they never loved it they are filthy when alone---. Self leaves out Christ, but God's work brings the low to trust, to venture all.

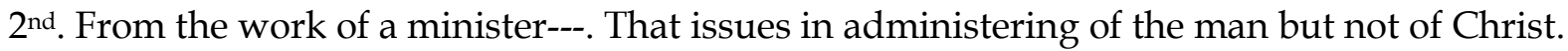
Great hostilities are wrought upon those and have something like that at Corinth. I am for Paul etc. ${ }^{50}$ But fall away when that minister dies or departs. But God's work has him primarily for the object of love, and ministers and Christians only as his servants and saints.

$3^{\text {rd }}$ From the coming work of God's Spirit himself. There is I think a coming work [unclear] There were some who always resisted the Holy Ghost as the governor of the world--his word reasons, persuades, threatens, strives and the Spirit works upon men's consciences[?]. But is not this mockery? No, it's not, as one says, in him they will convert, but to prove the contrary, and the need of special grace.

$4^{\text {th }}$. From all those extraordinary works of God upon the minds of men in ages past Balaam;51 Saul. ${ }^{52}$ These not sanctifying. Die the death etc. ${ }^{33}$ Some have thought God has revealed to them some future event by some impression, through something, and from there have concluded they were the favourites of heaven to whom God revealed his secrets. But suppose it were so: we see Balaam was the same. Saul was meeting the prophets but not the saints. Ps. 99:6. This work of God is peace[?] Here is something wrought that can never be learnt. The breath of life is breathed into them and behold they pray! A principle of life is formed in them and they love Lord God. Become susceptible of spiritual things. Desire and live upon spiritual things. As the principle of animal life requires nourishment and support from animal food so this from spiritual ... And exciting to [unclear] and resist opposition etc. but let us next attempt.

II. To confirm what is asserted that he that has begun this good work etc. The day of Jesus Christ may mean the day when Jesus Christ will deliver up his people to his Father. And perhaps the work of sanctification is never totally finished till our [unclear] bodies shall be changed.

Otherwise we might think the day of death meant.

But before we enter personally into this work of confirmation let us try and form an idea of the greatness of the work of carrying on this work. That we may love God for his promise; if it's a good work to begin it's a great work to carry on. The setting up of Christ's kingdom in the heart resembles the setting up a kingdom on earth and that will soon decay if not carried on with the same care \&c. Cyrus's \&c. ${ }^{4}$ This the cause of the decay of great empires. Their founders die and leave foolish children but Christ leaves. [Something missing from foot of page.]

This is a great work and requires great power, great love, great patience!--- He that will carry on such a work as this must have power enough to melt mountains of ice. (Repeatedly) subdue hills of corruptions. Absorb a sea of filthiness.--- He must enable weakness to contend with strength as if one should undertake to make a child of years old overcome an armed

\footnotetext{
50 1Cor. 1:12-13.

51 Num. 22-24.

52 1Sam. 10:10-13.

53 Num. 16:29.

54 Cyrus is represented as a tool in God's hand in Is. 44:28 \& Is. 45:1; he also aids Ezra throughout the book, and is mentioned in $2 \mathrm{Chr}$, and in Dan. Some composite of these references is presumably intended here.
} 
host of veterans! Yet so it is Josiah. ${ }^{55}$ the armies etc. ${ }^{56}$ The feeble soul[?] shall win the day though etc.

He must have great love he that will undertake to carry on this work must have to carry it on in spite of oceans of ingratitude. He must love a woman that is an adulteress! ${ }^{57} \mathrm{He}$ must have patience amid Christian proudness[?]. Yes, he must have the resolution of a God not to forsake his work. Well then it is for my own name's sake will I defer my anger that I cast thee not off. 58 He remembers his covenant with Jesus who...

But well may we question that he will thus carry it on. ${ }^{59}$ [This whole sentence not clear.]

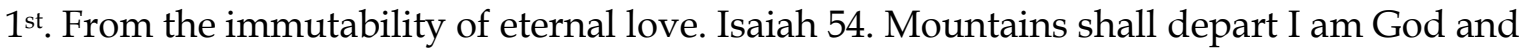
change not, etc.

$2^{\text {nd }}$. From the designs of God in eternal election to salvation through Son etc. my counsel shall stand.

$3^{\text {rd. }}$ From their being purchased by Christ. He shall see of the travail of his soul. $60 \mathrm{He}$ shall have the heathen for etc. ${ }^{61}$ of all that the Father gave him he would lose none nay nothing. His name is not only alpha but omega!

$4^{\text {th }}$. From the promise made to them that believe they shall be saved this implies that they shall persevere.

$5^{\text {th }}$. From what he has already done. Ebenezer. ${ }^{62}$ How often has he recovered you wretched soul, how often pardoned[?] your sin how often made mountains become plains how often renewed your strength when just ready to die. Perhaps you like David may conclude sometimes I shall one day etc. ${ }^{63}$ but would it not have been better he that hath delivered etc! ${ }^{64}$

Use 1. Let none abuse this truth and make it their only care to know the work has begun. Those aim at an impossibility. It is not begun where there is not an habitual desire to have it carried on and not only a desire- but a using all the means of grace that tend to carry it on.

2. Be reconciled to trying disciplines. These are the means God uses to awaken, reclaim and carry on.

3. Take courage ye that are engaged in Christ's cause. You fight in sure hope of victory does this tend to slacken a soldier's hand?

\section{Some initial reflections on the texts}

We have no other 'ordinary' sermons in print from this period of Fuller's life. The published material we have is from sermons preached before Association meetings, ${ }^{65}$ or particularly

\footnotetext{
55 Josiah was eight years old when he became king. 2Ki. 22:1.

56 This is perhaps a reference to David and Goliath, where the phrase 'the armies of the living God' appears repeatedly (1Sam. 17:26; 35, e.g.), but it is hard to be sure.

57 Hos. 1:2.

58 Is. $48: 9$.

59 The following list give reasons to believe God will carry the work on in the face of such questioning.

60 Is. 53:11.

61 Ps. 2:8.

62 1Sam. 7:12.

63 1Sam. 27:1.

64 Ps. 55:18.

65 e.g., 'The Nature and Importance of Walking by Faith', Fuller's first published work, preached before the Northamptonshire Association, June 2nd, 1784.
} 
important funeral sermons. ${ }^{66}$ Further, these published sermons have been worked up for publication by Fuller. These two sermons, then, and the others in the Bristol MS, represent a unique insight into the week-by-week preaching of Andrew Fuller at a formative stage in his life. Several features will immediately strike the reader:

1. The frequency of Biblical references will not be a surprise, but it is striking how many are taken from a relatively small portion of Scripture - the Saul cycle in 1Sam., from which come six of 39, or over $15 \%$. The most likely explanation might be that these narratives were uppermost in Fuller's mind, either because he had been reading them in private devotion, or because he had been lecturing through them in midweek meetings with the church. Old Testament references aboundaside from the sermon texts, only eight references are made to the NT, of which only one is to the Gospels. Scripture references appear to function in these two sermons either as the source of a lapidary statement of truth -'I am God and change not...' or as narrative illustrations of a point; the O.T. texts perhaps lend themselves better to the latter (particularly given the theme of both sermons is essentially divine providence in the vicissitudes of history).

2. This chosen theme is hardly a surprise-leaving his people, Fuller wanted to reassure them that his departure did not mean the departure of divine favour. The Romans text and sermon insists that God works all things for good, with an emphasis in the development on the various ways in which God brings good out of suffering or apparent evil. The Philippians sermon focuses on the sure promise that God's work will continue once begun-leading to final salvation, of course, but Fuller repeatedly implies, at least, a corporate application of the same principle: God is at work in the church at Soham, and will finish the work.

3. Both sermons contain strikingly theological moments. Do the 'all things' spoken of in Rom. 8:28 include human sin, Fuller asks in closing his morning sermon? He does not quite decide the question, although he seems to favour the affirmative, but he quickly excludes any possible suggestion that this excuses human sin. The evening sermon begins with the experimental question of how we can know that God has begun a work in our hearts, and moves quickly into areas of theological controversy around that question. The latter point would surely have been familiar to Fuller's hearers, so common was the question in seventeenth- and eighteenth-century nonconformity; the former might seem needlessly theoretical, but Fuller's practical applicationwe cannot excuse sin-makes it relevant to the sermon.

4. The use of illustration is powerful in both sermons. The passage early on in the morning sermon which moves from contrasting a well-ordered army and a disorderly mob, to reflecting on the ways the parts of a mill work together, to the various medicines used by a physician, to homely farming metaphors, offers a striking series of vivid images to carry its point. Similarly, the second point of the evening sermon begins with the maintenance of a realm, but then offers us mountains of ice, hills of corruptions, seas of filthiness, and oceans of ingratitude. These images are arresting and carry Fuller's point (although the reader might wonder how effectively images of mountains communicated to the fen-dwellers of Soham!).

5. Again, the use of rhetoric is powerful. 'he who has power enough to keep all things at work, and wisdom enough to cause them to work together, has love us enough to make them answer one invariable end, the good of his people.' is a remarkably well-crafted sentence, as is 'There is not only a work for us by Christ but in us by the Holy Ghost. Not only a word to us in the Scriptures but a work in us by the Spirit', to take only two examples. That said, both sermons seem to end fairly feebly, with a plea that time is gone in the morning (surely affected, in that it is preceded by brief notes of uses, which Fuller could have filled out as quickly or as fully as he chose), and with

${ }^{66}$ e.g., 'The Blessedness of the Dead who Die in the Lord,' printed in 1792, which was the funeral sermon for Fuller's deacon at Kettering, Beeby Wallis. 
the curiously limp line 'does this tend to slacken a soldier's hand?' In the evening. In both sermons, the 'uses' are brief, and so we must assume Fuller would be extemporising at some length here; perhaps he trusted in his abilities, and/or the inspiration of the Spirit, to find a powerful close, and thus did not craft one?

6. The sermons are strikingly unaffected in construction. The reader familiar with Puritan forms of the previous century - or even the sermons of Jonathan Edwards - will look in vain for the standard structural apparatus; no 'doctrine' is stated, defended, or developed. The key influence here is that of Jean Claude (1619-1687), a Huguenot pastor whose (lengthy) Essay on the Composition of a Sermon was published posthumously in his collected works. Robert Robinson, of [what is now] St Andrews Street Baptist Church, Cambridge, published a translation in $1778,{ }^{67}$ although he notes that he first translated it in 1766, and began adding notes, and he was clearly sharing his translation around, as he states that he was encouraged to publish it by friends in 1775. Fuller would later recommend Claude to young preachers. ${ }^{68}$ Claude's advice might be boiled down to the instruction to let the text dictate the form of the sermon, and we might see Fuller following that advice in these two manuscripts.

The influence of Claude on evangelical homiletics has been surprisingly unstudied, particularly given that his book was used in Charles Simeon's famous sermon class as well as by Baptists. ${ }^{69}$ Lessenich mentions him repeatedly, but in aid of a rather implausible thesis that reduces all eighteenth-century preaching to a sort of Anglican broad churchmanship. ${ }^{70}$ More recent, and better, accounts of the eighteenth-century sermon mention him only in passing, or not at all.71 Old comments that Claude was a part of the shift of French Protestant preaching from serial commentary on a passage to exposition of a text, defined as a unit of Scripture that contained one

${ }^{67}$ Jean Claude (tr. and annotated Robert Robinson), Essay on the Composition of a Sermon (2 vols) (London: Scollick, Wilson, \& Spence, $1788^{3}$ ).

68 See Fuller's 'Essay on the Composition of a Sermon...' in Anon, The Preacher, or Sketches of Original Sermons... (London: Richard Baynes, 1822), pp. 14-32, p. 32. This text is related to 'Letter 3' in the text Thoughts on Preaching in the Collected Works, but different in several respects; the CW edition does not mention Claude. It seems likely that the $C W$ edition is tidied up with other occasional letters into a single work by an editor, and so that the mention of Claude is original, but this cannot be proven. J.W. Morris asserts that Claude's Essay was 'one of the first books that Mr Fuller read, after entering on the ministry, and which he frequently recommended to others...' Morris, Memoirs, p. 69.

${ }^{69}$ In a perhaps revealing footnote, Hughes Oliphant Old comments ‘[a]s my research progresses, I am discovering that Jean Claude and Robinson's translation and commentary are very important. I regret not giving them more attention in my earlier studies.' Hughes Oliphant Old, The Reading and Preaching of the Scriptures in the Worship of the Christian Church (8 vols) Vol VI, The Modern Age (Grand Rapids: Eerdmans, 2007), p. 730 n. 37.

${ }^{70} \mathrm{He}$ asserts preachers 'endeavoured to present solid, uncontroversial truths' and that their 'Christianity appeared to be a system of moral precepts rather than one of doctrinal beliefs' Rolf P. Lessenich, Elements of Pulpit Oratory in Eighteenth-Century England (1660-1800) (Köln: Böhlau Verlag, 1972), both p. 234. Claude, the great Huguenot controversialist, and Fuller would alike have been surprised to find themselves so described.

${ }^{71}$ Jennifer Farooq, Preaching in Eighteenth-Century London (Woodbridge: Boydell, 2013) does not mention him at all, nor does James Downey, The Eighteenth Century Pulpit (Oxford: Clarendon, 1969). Ann Matheson, 'Preaching in the Churches of Scotland' in Keith A. Francis and William Gibson, eds, The Oxford Handbook of the British Sermon 1689-1901 (Oxford: OUP, 2012), pp. 152-168, mentions his work in a list of other homiletic manuals (pp. 160-161), but is the only contributor to that volume to do so. Peter Bayley, French Pulpit Oratory 1598-1650 (Cambridge: CUP, 1980) cites Claude's sermons, but not his treatise (e.g., p. 110); similarly, Didier Boisson, Consciences en Liberté? Intinéraires d'ecclésiastiques convertis au protestantisme (1631-1760) (Paris: Honoré Champion, 2009) has several references to Claude, but all to his role as a Huguenot controversialist (e.g. pp. 119; 130-2.) 
complete thought. ${ }^{72}$ Claude's influence on British nonconformist preaching is a similar shift, from preaching a doctrine (as Perkins had recommended ${ }^{73}$ and Edwards exemplified) to preaching a text; these sermons of Fuller's exemplify that shift.

72 Old, Reading and Preaching vol. IV: The Age of the Reformation (2002), p. 446.

${ }^{73}$ William Perkins, Prophetica, sive, De sacra et vnica ratione concionandi tractatus (Cantab.: Johannis Legatt, 1592); E.T. The arte of prophecying, or, A treatise concerning the sacred and onely true manner and methode of preaching (London: Felix Kyngston for E.E, 1607). 